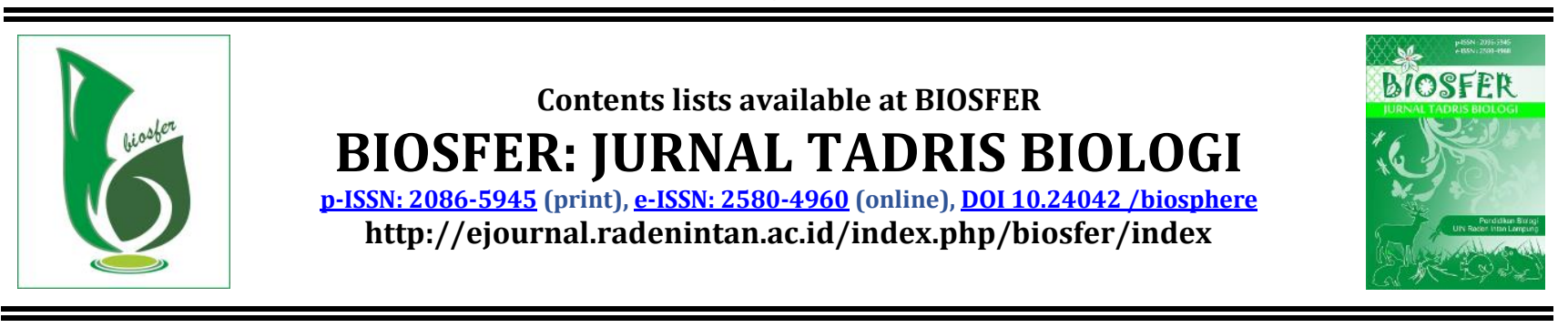

\title{
An Analysis of Critical Thinking Skills; Global Warming Learning Materials
}

\author{
Nur Eka Kusuma Hindrasti1 ${ }^{*}$; Nurul Asikin²; Wika Khairinnisa3 \\ 1,2,3 Biology Education FKIP UMRAH Riau, Indonesia
}

\begin{tabular}{ll}
\hline ARTICLE INFO & ABSTRACT \\
\cline { 1 - 2 } Article History & $\begin{array}{l}\text { This study aimed to analyze students' critical thinking skills levels on } \\
\text { global warming materials. This quantitative descriptive study employed }\end{array}$ \\
Received $: 01-02-2020$ & $\begin{array}{l}\text { the cluster random sampling technique. The analyzed data were the } \\
\text { students' critical thinking skills. Researchers collected the data using }\end{array}$ \\
$\begin{array}{l}\text { Published }: 28-08-2020 \\
\text { critical thinking skills test instruments in the form of description } \\
\text { questions and open-ended questionnaires. Furthermore, the data were } \\
\text { analyzed using statistical formulas in the form of percentages. Based on } \\
\text { the data analysis results, the percentage of students' critical thinking }\end{array}$ \\
$\begin{array}{l}\text { Critical Thinking Skills; } \\
\text { Global warming; }\end{array}$ & $\begin{array}{l}\text { skills score was } 65 \% \text { and was categorized at a moderate level. Therefore, } \\
\text { the researchers concluded that students' critical thinking skills on global }\end{array}$ \\
Science Learning & warming learning materials are moderate. Thus, there needs to be an \\
effort to improve students' critical thinking skills.
\end{tabular}

*Correspondence Address:

Khairinnisawika@gmail.com

\section{Analisis Keterampilan Berpikir Kritis Pada Pembelajaran Pemanasan Global}

\begin{abstract}
Abstrak: Tujuan dari penelitian ini adalah untuk menganalisi tingkatan keterampilan berpikir kritis peserta didik pada materi pemanasan global. Penelitian deskriptif kuantitatif ini menggunakan teknik Cluster Random Sampling. Data dalam penelitian ini adalah keterampilan berpikir kritis siswa. Peneliti mengumpulkan data menggunakan instrumen tes keterampilan berpikir kritis berbentuk soal uraian dan angket terbuka. Selanjutnya data dianalisis menggunakan rumus statistik berupa persentase. Berlandaskan hasil analisis data diperoleh bahwa persentase skor keterampilan berpikir kritis peserta didik yaitu 65\% yang dikategorikan pada tingkatan sedang. Sehingga peneliti menyimpulkan bahwa keterampilan berpikir kritis peserta didik pada materi pemanasan global pada tingkatan sedang. Dengan demikian perlu adanya upaya untuk meningkatkan keterampilan berpikir kritis siswa.
\end{abstract}

\section{INTRODUCTION}

In the modern era full of technology and information, life has become more sophisticated with significant changes
(Ameliola \& Nugraha, 2013; HASANAH et al., 2019). Development requires a new paradigm to create a better generation who has high competence in controlling 
society's life and welfare (Hazami, 2016; Roqib, 2009; Suhaimi, 2016). (Aka, 2017; Ameliola \& Nugraha, 2013; Ariani \& Festiyed, 2019) The future demands the preparation of skilled and expert personnel in educational technology, especially those related to competencies that must be mastered in the learning process (Bahar, 2019; Budiman, 2017).

The rapid globalization has led to competition in various fields of life and education, especially science education (Langke, 2019; Rahma, 2012; Suriana, 2014). To face tough challenges, it is crucial to improve the quality of education. Increasingly rapid technological advances require education to continue to develop and produce high-quality human resources (HR) who can think critically, creatively, systematically to solve problems and have good morals (Permatasari et al., 2018; Purwati et al., 2016; Sitohang, J. M, 2018). Critical thinking skills are necessary to possess because they can be used to solve all problems. They are also considering making a reasonable decision about what can be trusted and done (Chotimah et al., 2019; Nafiah \& Suyanto, 2014; Zubaidah, 2010), (Alifah \& Aripin, 2018).

Self-regulation is an aspect to examine self-cognitive activities, the elements, and the results using analysis and evaluation skills. It is ultimately used to confirm, validate, and re-correct reasoning (Alfina, 2014; Hidayat, 2013; Mulyani, 2013). Self-regulation can regulate students in problem-solving and activities (Arismawati et al., 2017).

Problems can be indications of the inappropriate use of the learning model. Therefore, the students' critical thinking skills cannot be optimized even though critical thinking skills are one of students' skills.

The quality of the skills is very important to achieve goals. Critical thinking skills are used to understand and state the meaning or purpose of experiences, situations, data, events, decisions, conventions, beliefs, rules, procedures, or criteria. They are also used to identify the meaning of the correct conclusion between statements, questions, concepts, belief-based descriptions, decisions, experiences, reasons, information, or opinions. Similar research has been conducted that measures the importance of critical thinking skills (Alifah \& Aripin, 2018), critical thinking skills and solving math problems based on the cognitive style (Asmawati, 2015), the guided-inquiry model worksheets on mathematical thinking skills (Christiyanto et al., 2018), and creative thinking using handouts (Hasanah et al., 2018).

Previous research examined global warming on contextual learning-based science magazine development (Asfuriyah \& Nuswowati, 2015) and developing a theme module (Asfuriyah \& Nuswowati, 2015; Rizqi et al., 2013). Puspita states that critical thinking skills can help someone overcoming his simple to complex daily problems (Puspita \& Putri, 2020). Based on several research results, critical thinking skills are needed by students to solve problems. This research's novelty is critical thinking skills in global warming by analyzing critical thinking skills on global warming material.

\section{METHOD}

This research was conducted at SMP Negeri 7 Tanjung Pinang in the second semester of the 2018/2019 academic year. The study employed descriptive research with a quantitative approach. The research design consisted of two stages: the preparation stage (compiling proposals, preliminary observations, making instruments, validation, and testing) and the implementation stage (data collection, data analysis, and conclusion). The research data were critical thinking skills. The instrument was developed by constructing HOTS questions based on the 
level of cognition and the 2013 curriculum. The data were analyzed using the Pearson Product Moment correlation technique. The formula used to calculate the reliability of the data was the Cronbach-Alfa $(\alpha)$ formula.

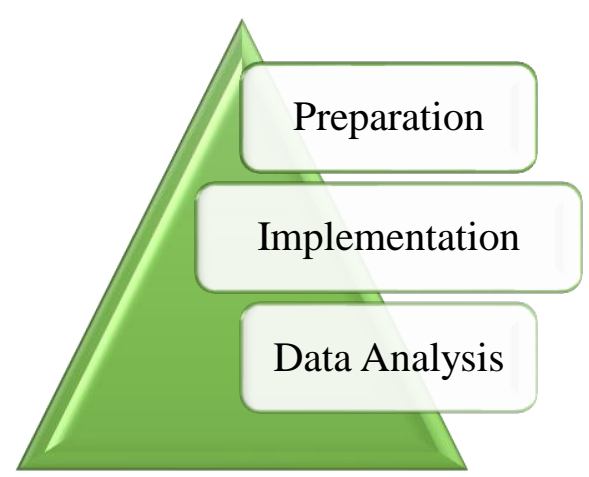

Picture 1: Research Framework

The population in this study was 200 seventh-grade students. Through a cluster random sampling technique, 127 students were selected as the samples. The data were collected using a test (question) and non-test (open-ended questionnaire) instruments. The test consisted of ten description questions based on the aspects of critical thinking skills, according to Facione (2015). The data analysis technique used was in the form of percentages. The critical thinking skills were categorized into five categories: poor (50\%), low (60\%), moderate (63\%), high (75\%), and excellent (80\%).

\section{RESULTS AND DISCUSSION}

The test results are presented in Table 1 below.

Table 1. The Percentages of Critical Thinking Skills

\begin{tabular}{ccc}
\hline CBC aspects & Percentage & Category \\
\hline Interpretation & $60 \%$ & Low \\
Analysis & $63 \%$ & Moderate \\
Evaluation & $70 \%$ & Moderate \\
Inference & $64 \%$ & Moderate \\
Explanation & $66 \%$ & Moderate \\
Self-regulation & $68 \%$ & Moderate \\
\hline Average & $65 \%$ & Moderate \\
\hline
\end{tabular}

Based on Table 1, it can be seen that the students' critical thinking skills were in the medium category. This can also be seen from each aspect of the average percentage obtained in the medium category. Only the
Interpretation aspect was in a low category because the students could not classify data in detail. For more details, the percentage of aspects of critical thinking skills can be seen in Figure 2. 
Biosfer, 11 (2) (2020) 121-128

Nur Eka Kusuma Hindrasti, Nurul Asikin, Wika Khairinnisa

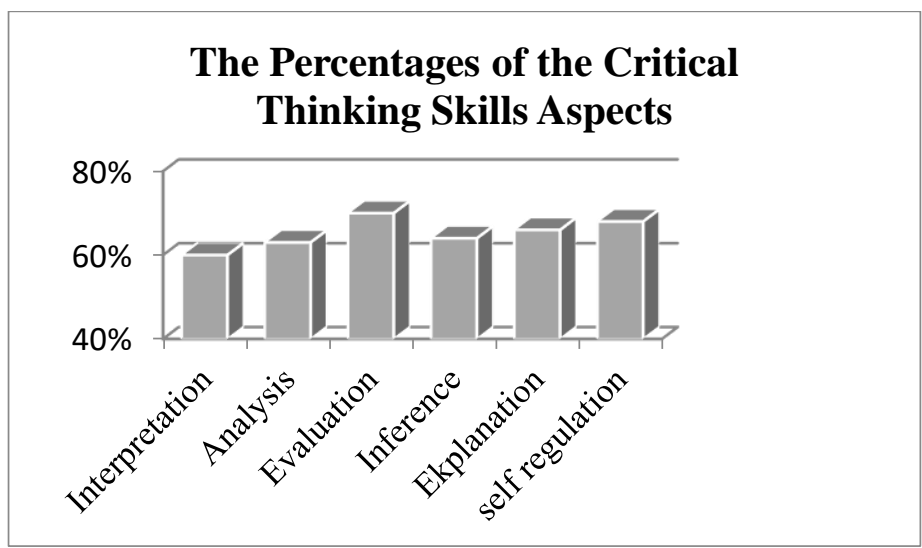

Figure 2. The Percentages of the Critical Thinking Skills Aspects

The low interpretation category was caused by students' inability to interpret data in a table or graph formats. Based on the students' answers, they did not understand how to interpret the data correctly. Only several students can group the data based on graphs. Some other students only provided conclusions based on the questions presented about the increased carbon dioxide concentration that is not always followed by temperature changes. However, the relationship between the carbon dioxide increase and the temperature on the earth's surface is that the increased concentration of $\mathrm{CO} 2$ gas will affect the level of heat on earth. The following are the aspects of critical thinking skills used to measure one's critical thinking skills:

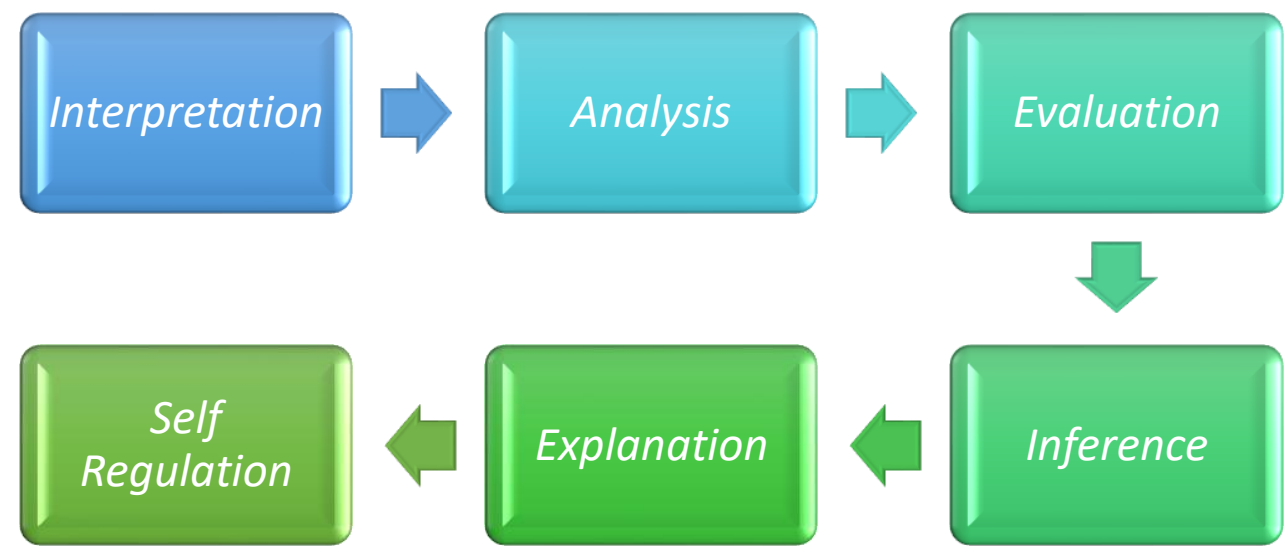

Figure 3. Critical Thinking Skills Aspects

The students' second aspect of critical thinking skills, Analysis, was categorized as moderate. The students could analyze problems in a given discourse. They were given information related to the causes of the melting of the north polar ice. In the analysis aspect, some students could answer the questions correctly because they followed the appropriate steps in analyzing a question. However, some could not analyze the problem based on the information because, during the learning process, they did not understand how to analyze the teacher's problems (Pratiwi, 2014). They could not understand and find problems in a question. The openended questionnaire found out that they did not know how to analyze a problem properly. They have difficulty solving problems. Thus, when the test was administered, some students could not answer correctly.

The students' third aspect of critical thinking (Evaluation) was in the the moderate category. However, the 
percentage of this aspect was the highest compared to the other aspects. The students were given a question regarding the use of a spray that has a negative impact on the earth's ozone layer. Many students answered according to their arguments and provided good responses and solutions. However, several students did not answer properly and some others provided solutions without responding to the problem first. This result is in line with the research conducted by Purwasish (Purwasih, 2015) that the evaluation aspect deserves the highest score because it is the habit during the learning process that students are always trained in solving problem-based questions. Students are required to practice in providing argument and assessments. The students' questionnaire answers reinforced the percentage in the Evaluation aspect. Providing an argument for an event can be done by giving suggestions or criticisms correctly based on the questions.

The percentage of students' fourth aspect of critical thinking (conclusion) was in the moderate category. The strategy in providing conclusions is to read the entire discourse content in a question, then respond and conclude correctly. The presented problem was related to the environmental pollution problems, and the air temperature increase is causing forest fires. Based on the answers, most students answered by providing solutions instead of giving conclusions.

The results align with Pritananda's research regarding the Inference aspect (conclusion) (Pritananda, 2017) that students cannot use relevant information to solve problems. They could not make suitable alternative solutions and conclude the problem. The questionnaire's data reinforced the data that many students did not know how to make good conclusions to only provide suggestions on the problem.
The percentage of students' fifth critical thinking aspect (explanation) was in the moderate category. The students were given a question about cities that produce the same number of molecules. The idea must be accompanied by analysis beforehand so that it is easy to explain. From the students' answers, some of the students were wrong in explaining the discourse's content. Before explaining, they had to analyze first. Some students could not do the analysis. Some answers were inappropriate with the question's instructions. These results were in line with research conducted by Ayuningtyas (Ayuningtyas et al., 2017; Sajidan Susilowati \& Ramli, 2017) that in the Explanation aspect, students need many practices in formulating problems. Based on the questionnaire's responses, it can be concluded that some students did not know how to describe the concept correctly, and according to the procedure.

In the sixth aspect (Self-regulation), the students were categorized in the moderate category. They were given ideas that must be developed in protecting the environment. Based on their answers, they poured their ideas correctly and clearly. The idea was relevant to the everyday life application. However, several students had not implemented these ideas. Based on the questionnaire's responses, many of the solutions have been applied in everyday life. The research results in this aspect are in line with research conducted by Indriawati (Indriawati et al., 2016; Susilowati Susilowati, 2018) in the aspect of selfregulation. Averagely, the students could apply this aspect in the learning process and monitor their learning controls. The proportion of answers was not evenly distributed caused by weaknesses of the textbooks used even though many supporting books presented in encouraging students to use higher-order thinking (critical, creative, and analytical thinkings) (Febrian et al., 2013; Giani et al., 2015). Simultaneously, it is related to 
higher-order thinking skills, one of which is analyzing and solving problems in everyday life.

\section{CONCLUSIONS AND SUGGESTIONS}

Based on the analysis results, it can be concluded that students' critical thinking skills on global warming learning material were in the medium category. It can be seen in the students' average percentage score and their critical thinking skills indicators' achievement. The average of students' category was moderate, with the Evaluation as the highest aspect and the Interpretation as the lowest aspect. Future researchers who want to research critical thinking skills analysis can develop even better test instruments. They should use words that are effective and easy for students to understand. It is also suggested to use indicators of critical thinking skills based on other experts, different materials, and different subjects. The suggestions should be made so that the research can be more varied. This study could be used as a reference for further research.

\section{REFERENCES}

Aka, KA (2017). Utilization of Information and Communication Technology (ICT) as a form of learning resource innovation in elementary schools. ELSE (Elementary School Education Journal): Journal of Elementary School Education and Learning, 1 (2a).

Alfina, I. (2014). The relationship between self-regulated learning and academic procrastination in accelerated students. Psikoborneo, 2 (1).

Alifah, N., \& Aripin, U. (2018). Thinking Process of Junior High School Students in Solving Mathematical Problems in terms of Field
Dependent and Field Independent Cognitive Style. JPMI (Journal of Innovative Mathematics Learning), 1 (4), 505-512.

Ameliola, S., \& Nugraha, HD (2013). Development of information media and technology for children in the era of globalization. Proceedings of the International Conference On Indonesian Studies "Ethnicity And Globalization.

Ariani, R., \& Festiyed, F. (2019). Analysis of Educational Science and Technology Foundation in Interactive Multimedia Development. Journal of Physics Learning Research, 5 (2).

Arismawati, U., Djamillah Bondan, W., \& Si, M. (2017). The effectiveness of the problem based learning model is viewed from the problem-solving abilities and self-confidence of grade VII students of SMP Negeri 1 Sanden, Yogyakarta. Journal of Mathematics Education, 6 (9), 919.

Asfuriyah, S., \& Nuswowati, M. (2015). Science Magazine Development Based on Contextual Learning on the Theme of Global Warming to Increase Student Interest in Learning. Unnes Science Education Journal, 4 (1).

Asmawati, EY (2015). Student worksheets (LKS) use the guided inquiry model to improve students' critical thinking skills and conceptual mastery. Journal of Physics Education, 3 (1).

Ayuningtyas, P., Soegimin, WW, \& Supardi, ZI (2017). Development of Physics Learning Tools with Guided Inquiry Models to Train High School Students' Science Process Skills on Static Fluid 
Biosfer, 11 (2) (2020) 121-128

Nur Eka Kusuma Hindrasti, Nurul Asikin, Wika Khairinnisa

Materials. JPPS (Journal of Science Education Research), 4 (2), 636647.

Bahar, B. (2019). Smart Lks: Mobile Technology-Based Learning Application Model for Post-Class Enrichment of Elementary School Teaching Materials. Journal of Information and Communication Technology, 10 (1), 1-5.

Budiman, H. (2017). The role of information and communication technology in education. AlTadzkiyyah: Journal of Islamic Education, 8 (1), 31-43.

Chotimah, S., Ramdhani, FA, Bernard, M., \& Akbar, P. (2019). The Effect of Model-Eliciting Activities Approach on Mathematical Thinking Ability of State Junior High School Students in Cimahi City. Journal on Education, 1 (2), 68-77.

Christiyanto, DY, Sulandra, IM, \& Rahardi, R. (2018). Reflective Student Critical Thinking Process in Solving Mathematical Problems in the Material of Two Variable Linear Equation Systems. Journal of Education: Theory, Research, and Development, 3 (10), 13471358.

Febrian, DW, Wardono, W., \& Supriyono, S. (2013). TGT learning through PMRI approaches assisted by traditional games on creative thinking skills. Unnes Journal of Mathematics Education, 2 (2).

Giani, G., Zulkardi, Z., \& Hiltrimartin, C. (2015). Cognitive level analysis of seventh grade mathematics textbook problems based on Bloom's taxonomy. Journal of Mathematics Education, 9 (2), 7898.
Hasanah, U., Gummah, S., \& Herayanti, L. (2018). The difference in the results of students' critical thinking and creative thinking skills using problem-solving based handouts. Prism of Science: Journal of the Study of Mathematics and Natural Sciences Learning and Science IKIP Mataram, 6 (1), 38-45.

HASANAH, UN, Thahir, A., Komaruddin, K., \& Rahmahwaty, R. (2019). MURDER Learning and Self Efficacy Models: Impact on Mathematical Reflective Thingking Ability. Journal for the Education of Gifted Young Scientists, 7 (4), 1123-1135.

Hazami, B. (2016). The role and application of Waqf in realizing the welfare of the people in Indonesia. Analysis: Journal of Islamic Studies, 16 (1), 173-204.

Hidayat, AF (2013). The relationship between self-regulation and learning achievement in calculus ii is viewed from the aspects of metacognition, motivation and behavior. Tadulako Mathematics Education Electronic Journal, 1 (1).

Indriawati, A., Susilowati, SME, \& Supardi, KI (2016). Problem-Based Learning with Aquatic Resources Oriented Teaching Materials Against Character Caring for the Environment and Science Learning Outcomes. Journal of Primary Education, 5 (2), 88-96.

Langke, R. (2019). Religious Education in the Global Era. The Scientific Journal of Iqra ', 13 (2), 54-69.

Mulyani, MD (2013). The relationship between time management and self regulated learning in students. 
Educational Psychology Journal, 2 (1).

Nafiah, YN, \& Suyanto, W. (2014). Application of problem-based learning models to improve critical thinking skills and student learning outcomes. Journal of Vocational Education, 4 (1).

Permatasari, CL, Nawati, I., Yanti, TW, \& Kusumawardhany, ZS (2018). Competence of Office Human Resources in the Millennial Era. Proceedings of the National Seminar on Office Administration Education.

Pratiwi, TP (2014). Strategies for Increasing Local Own Income, Investment and Economic Growth in the City of Semarang through MICE (Meeting, Incentive, Convention and Exhibition). Economics Development Analysis Journal, 3 (1).

Pritananda, R. (2017). Students' Critical Thinking Ability in the Aspect of Inference in Solving the Pythagorean Theorem Story Problem. Tanjungpura University.

Purwasih, R. (2015). Improved Mathematical Understanding Ability and Self Confidence of MTS Students in Cimahi City through Guided Inquiry Learning Model. Didactic, 9 (1), 16-25.

Purwati, R., Hobri, H., \& Fatahillah, A. (2016). Analysis of Students' Critical Thinking Ability in Solving Quadratic Equation Problems in Creative Problem Solving Model Learning. KadikmA, 7 (1), 84-93.

Rahma, AN (2012). Development of Inquiry Model Learning Tools with SETS Approach for Solubility and Solubility Results to Foster
Students' Critical Thinking Skills and Empathy for the Environment. Journal of Research and Educational Research Evaluation, 1 (2).

Rizqi, A., Parmin, P., \& Nurhayati, S. (2013). Development of an Integrated Science Module with Global Warming Themes for Junior High School Students. Unnes Science Education Journal, 2 (1).

Roqib, M. (2009). Islamic Education; Development of Integrative Education in Schools, Families and Communities. LKIS Pelangi Aksara.

Sitohang, JM (2018). The Effectiveness of the Use of Macromedia Flash 8 Assisted $\mathrm{Pbl}$ Learning Model Against the Critical Thinking Ability of Class X Students at SMA Negeri 1 Batangtoru. ). MathEdu Journal (Mathematic Education Journal, 1 (3), 52-60.

Suhaimi, S. (2016). The Role of Higher Education in the Development of Professional Competence for Prospective Educators. EDUCASIA: Journal of Education, Teaching, and Learning.

Suriana, S. (2014). Islamic Education in the Era of Globalization: Seizing Opportunities, Reaping Challenges. MUDARRISUNA Journal: Media Studies for Islamic Religious Education, 4 (2), 356-375.

Susilowati, Sajidan, \& Ramli, M. (2017). Analysis of critical thinking skills of state madrasah aliyah students in Magetan district. National Seminar on Science Education, 21, 223-231.

Susilowati, Susilowati. (2018). Feminist Therapy as an alternative to the 
Biosfer, 11 (2) (2020) 121-128

Nur Eka Kusuma Hindrasti, Nurul Asikin, Wika Khairinnisa

prevention of sexual harassment in women. Proceedings of the National Seminar on Guidance and Counseling, 2 (1), 213-220.

Zubaidah, S. (2010). Critical Thinking: Higher-Order Thinking Skills That Can Be Developed Through
Science Learning. National Seminar Paper on Science with the theme of Optimizing Science to Empower Humans. Postgraduate Unesa, 16. 